\author{
Marta Sikorska \\ University of Gdansk \\ e-mail: marta.sikorska@ug.edu.pl \\ ORCID: 0000-0001-8598-4077
}

\title{
CORPORATE SOCIAL RESPONSIBILITY IN ISLAMIC BANKS
}

DOI: 10.15611/pn.2020.12.09

JEL Classification: M14

(C) 2020 Marta Sikorska

This work is licensed under the Creative Commons Attribution-ShareAlike 4.0 International License. To view a copy of this license, visit http://creativecommons. org/licenses/by-sa/4.0/

Quote as: Sikorska, M. (2020). Corporate social responsibility in Islamic banks. Prace Naukowe Uniwersytetu Ekonomicznego we Wrocławiu, 64(12).

\begin{abstract}
The main objective of this article is to examine to what extent the banks operating in accordance with Sharia law consider the concept of corporate social responsibility as an overriding priority. As a thesis, the statement has been adopted that the religion of Islam significantly contributes to the application of this concept in Islamic financial institutions. To verify this thesis statement, a literature overview and induction study methods were used. In addition, a study of the information provided by selected banks operating in accordance with Sharia law, with offices in the United Kingdom, Saudi Arabia and Kuwait, was carried out. The examination allows to conclude that Sharia law has a significant impact on the concept of corporate social responsibility in Islamic financial institutions. Islam recognizes this concept as paramount in the functioning of entities. In fact, every institution works to make a profit. In the functioning of Islamic entities, however, it is important that an entity making a profit does not overlook the moral and ethical norms that are characteristic of Islam and, most importantly, does not neglect fair tax calculation.
\end{abstract}

Keywords: corporate social responsibility, Islamic accounting.

\section{Introduction}

Corporate social responsibility (CSR), in the era of high company competitiveness, builds a company's advantage in its relations with customers. Company profitability is still most significant, but it is also important how the company affects the environment. Corporate social responsibility allows for the creation of a company's proper image, enabling it to stand out from other companies, thus increasing the demand for its goods. 
The above-described concept functions both in economics and management. It bloomed during the second half of the $20^{\text {th }}$ century, although references to this topic had been made before. Nowadays the concept of corporate social responsibility is closely linked to that of sustainable development. The need for this was first formulated in 1972 during a conference in Stockholm. It was not until the 1990s, however, that CSR began to gain importance. It was then pointed out that profit maximization is not enough to increase an economy's efficiency - running a responsible business, i.e. one that takes into account the wellbeing of all stakeholders, is important as well (Buczkowski, Dorożyński, Kuna-Marszałek, Serwach, \& Wieloch, 2016, pp. 11-13).

Enterprises try to build competitive advantage not only based on their financial results, but also by ensuring sustainable development. Every so often, however, corporate social responsibility is to a degree imposed by the regulations under which enterprises operate, as in the case of Islamic accounting. While acting in accordance with Sharia law $^{1}$, institutions should apply the concept of corporate social responsibility as the superior one. This means that entities are obliged to calculate Zakat ${ }^{2}$ fairly, and also to treat employees in a responsible manner, take care of the natural environment, support charitable organizations and comply with the moral and ethical norms that are characteristic of Islam. However, the questions arise whether this is only a utopian vision of an ideal Islamic enterprise, or these ideas are applied in practice and whether such institutions actually exist. As such, it seems important to examine if Islamic financial institutions are guided by Sharia law, and thus perceive the concept of corporate social responsibility as supreme.

Among the studies addressing this topic, it is worth mentioning a publication by Cieślewicz (2013), which compared corporate social responsibility in financial institutions, both in Europe and in Islamic countries. The author indicated that in Muslim countries, banks are primarily accountable to God, therefore they are guided by Sharia law. This means that the overriding goal of their functioning is to promote justice, which is reflected in their social responsibility. Zaman (2005), in turn, conducted a study comparing capitalist and Islamic economies. The main conclusion was that, apart from the interest in the growth and development of the economy, Islam is also oriented towards the idea of social justice. Jaworska (2011, p. 83) emphasized the role of this concept, proving that while developing accounting standards, the AAOIFI (Accounting and Auditing Organization of Islamic Institutions) also clarified

${ }^{1}$ Sharia - Muslim religious law providing guidelines regarding a Muslim's obligations to God Allah and to other people. Sharia consists of: Quran - the holy book of Muslims, Sunni - a collection of stories about the life of Muhammad, in the form of hadiths and various legal opinions issued by Muslim clergy (Janus, 2012).

${ }^{2}$ Zakat - one of the five pillars of faith, in Islam alms. A type of compulsory tax for the Muslim community, which applies to any adult Islam follower who owns property or has specific annual income. Centuries of lawyers' findings led to the creation of a complicated system for calculating, collecting and distributing Zakat. In many Muslim countries, it functions as a state tax. (Wielka Encyklopedia $P W N, 2005$, p. 201). 
the issue of corporate social responsibility. Jusoh and Ibrahim (2016) carried out a detailed study on the operation of the Bank Islam Malaysia Berhad, based on which they proved that this entity constitutes an ideal example of an Islamic institution implementing the concept of corporate social responsibility at all levels of its activity. It is also worth looking at the publications on corporate social responsibility of financial institutions. Waliszewski (2018, pp. 125-144) wrote about the CSR benefits and costs of these entities, while Korenik (2011) described the controversy around corporate social responsibility in commercial banks. The main one being that it is the expectations of shareholders, not other stakeholders, that should be satisfied first, and thus the bank should strive to maximize profit. However, she concluded that in order to operate as efficiently as possible, banks must use all the values of the environment in their activities, including natural resources, human capital and the possibility of cooperation with local communities.

\section{Corporate social responsibility}

The literature on the subject presents many definitions of corporate social responsibility. The European Commission defines it as a company's responsibility for its impact on society (Buczkowski et al., 2016, p. 14). This issue was defined more broadly by ISO 26000 . According to this regulation, it entails an organization's responsibility for the impact its activities and decisions have on society and the environment, owing to the ethical behaviour, which in turn contributes to prosperity, society's health and sustainable development, taking into account the stakeholders' expectations and at the same time acting in accordance with the law and the norms of behaviour consistent with the organization itself (Rojek-Nowosielska, 2017, p. 215). The World Business Council for Sustainable Development, in turn, states that corporate social responsibility means a company's commitment to ethical behaviour and its contribution to economic development by improving the living conditions of employees and their families, local communities and society in general (Koneczna, 2014 , p. 19). Although these definitions vary, they have a common denominator the company's positive impact on the relations with the environment.

There are different models of social responsibility. One of the best-known is the Carroll Model of CSR, in the form of a pyramid, based on economic responsibility, which is related to the fact that primarily a company is to be profitable, or at least not loss-generating, which is what society wants. It should also maintain a strong competitive position on the market and a high level of work efficiency. Legal responsibility, as demanded by society, a functioning enterprise is obliged to comply with the law (Rybak, 2001, pp. 29-30), which is ranked higher. A company is required to act as expected by the government and the law, as well as to provide goods and services that meet at least the minimum legal requirements. Society also expects institutions to be guided by ethical responsibility, which in practice means acting in a fair and equitable manner, where legal regulations are lacking, and the 
avoidance of ethical standard violations, in order to achieve their own goals. An entity's philanthropic responsibility, ranked higher than the other three, is associated with the allocation of part of the resources to programmes that support citizens as well as with involvement in the initiatives for the benefit of the local community (Carroll, 1991, as cited in: Koneczna, 2014).

Corporate social responsibility should be treated as an enterprise management tool. As such, how is one to assess whether a given entity is socially responsible? Assessment criteria include the following: organizational order, human rights, employee internship, environment, business ethics, customer-related issues, and social development. (Koneczna, 2014, p. 53). When assessing an enterprise's organizational order, attention should be paid to its compliance with the law and business ethics as well as its transparency. When deciding whether human rights are respected, political and civil rights (e.g. the right to freedom) as well as economic, cultural and social rights (e.g. the right to work, study and food) should be taken into account. It is also very important to treat employees properly, that is, to provide them with appropriate working conditions, social care, health and safety, human capital development, as well as to enable association within trade unions. Indispensable elements of corporate social responsibility also entail environmental protection and conducting business in an ethical manner, thus ensuring fair competition, respect for property rights, and the prevention of corruption or embezzlement. Education and awareness, protection of consumers' health and safety, sustainable consumption, as well as appropriate customer relations, involvement in the activity of local communities and participation in economic growth are the last group of the factors mentioned, but equally importantly to be assessed when verifying a given entity in terms of its social responsibility.

The particular significance of corporate social responsibility is observed in Islamic institutions operating in accordance with Sharia law.

\subsection{Corporate social responsibility in Islamic accounting}

Islam is a monotheistic religion that emerged on the Arabian Peninsula in the first decades of the $7^{\text {th }}$ century. It is based on the subordination of all spheres of human activity to the will of Allah - the only God. In practice, it means that religion also affects the shape of accounting in Islamic countries and differentiates it very much from traditional accounting. As a result, in 1991 a Bahraini nonprofit organization the Accounting and Auditing Organization of Islamic Financial Institutions (AAOIFI) - was founded. Its task is to develop accounting, auditing and professional-ethics standards and models of compliance with Sharia law for Islamic financial institutions.

The activity of Islamic institutions should be strictly regulated under Sharia law. The overriding purpose of the information generated by Islamic accounting is to assess whether a given entity applies, and to what extent it implements the principles of Shariah. The pillars of Islam that should be considered when running a business entail the principles of: 
1. Multifaceted ownership, according to which Allah is the owner of everything, and people are mere trustees, who are to responsibly dispose of property, in favour of social interest.

2. Economic freedom, the limits of which are set by religious values.

3. Social justice (Adamek, 2012, p. 43).

The last of these principles were discussed later in the article and constituted the basis for the research carried out.

The Islamic idea of social justice is based on the principles of mutual responsibility and balance. This means that, although differences in the level of the citizens' wealth are permissible, a situation where a small percentage of people are rich while the majority suffer from hunger and misery is not allowed. The concept of social responsibility is considered to be superior in Islamic accounting. This means that in order to preserve the content of the Quran, the holy book of Islam, institutions should calculate Zakat in the most honest way, reduce the negative impact on the natural environment to the minimum, treat employees with dignity, implement the moral and ethical norms characteristic of Islam, and to do charitable work (Adamek, 2012, p. 45).

The close relationship between economics, religion and ethics also affects the legal regulations which Islamic institutions are subject to, also in the field of social responsibility. This is manifested in the regulations addressing the Zakat tax - a tool used to provide material security for poorer Muslims, as well as in the ban on the calculation and collection of interest - the Riba.

Zakat is one of the five pillars of Islam, serving as a tool for distributing wealth from rich members of the society to the poor, and fulfilling the religious duty to Allah. This duty also has a number of other important functions. It stabilizes prices, and increases the money supply, thus stimulating an increase in the demand for goods and services, as well as serves as a tool to fight recession using the funds accumulated through it. It defines the development directions for the Islamic economy by indicating the sources of income that are subject to tax and, most importantly, by constituting a fiscal mechanism, thus providing education, health care and social benefits.

Sharia law also implies the idea of Riba - the ban on charging and collecting interest. According to Nabil Saleh (1986, as cited in: Adamek, 2012), interest is considered to be an unlawful profit, which stems from the uneven value of the mutual exchange of various things of the same kind. Riba is one of the most recognizable elements of the Islamic accounting doctrine. Interest that is treated as ex-ante income, determined irrespective of the outcome of a given venture, is strictly prohibited. The literature on the subject lists many arguments that negate the existence of interest. Interest that is treated as a reward for saving has no moral justification, while a financial reward in the form of interest cannot result from abstaining from incomerelated consumption. What is more, a share in profit or loss, instead of interest, is more advantageous, because the profit may exceed the market interest rates and thus be higher than in the case of traditional interest application (Adamek, 2012, p. 46). 
Islamic accounting strongly depends on Sharia law. The obligation to pay Zakat and the ban on calculating and charging Riba constitute Sharia guidelines and the very important principles of Islamic accounting. In order to prepare a financial statement for an Islamic institution in a correct and reliable manner, one should be guided by the main assumptions underlying the rights established by the Quran.

\section{Corporate social responsibility in Islamic banks}

In order to analyse corporate social responsibility in Islamic banks, the information provided by banks with headquarters in Arab countries - in Saudi Arabia and Kuwait - was selected. Banks from Great Britain were also chosen to verify the situation in a country where Islam is not the leading religion.

Among the Saudi Arabian banks, the Riyad Bank and the Arab National Bank (ANB) were examined.

The Riyad Bank has been operating in Saudi Arabia since 1957. It is one of the largest financial institutions in the Middle East. It provides retail and corporate clients with a wide range of products and services that are fully compliant with Sharia law. The Riyad Bank's priorities include the honest calculation of Zakat, which has been confirmed by the independent Shariah Supervisory Board. The Bank underlines the fact that the values it represents constitute the basis of its policy and its sustainable development strategy, which improves the overall situation of its employees, customers, shareholders and the entire Saudi Arabian community. The Riyad Bank partners many institutions, societies and charity organizations, inter alia: it sponsors the activity of the Summer Center at the King Khalid Female Charity Society in Tabuk and the summer club at the Disabled Children's Association in Al-Baha. It also demonstrates its care for the environment by developing initiatives that increase people's awareness of this issue. The Bank pays great attention to its employees, develops their skills, increases their opportunities and enhances their work. It received the prestigious Excellence In Talent Management Award twice and in 2017 was awarded the title of the best employer in the country.

The Arab National Bank (ANB), founded in 1979 and based in Saudi Arabia, offers commercial and investment banking services to both retail and corporate clients. It confirms its subordination to Sharia law in the area of Zakat calculation as well by offering interest-free products, which is overseen by the independent Shariah Supervisory Board. The Bank highlights its social-responsibility activity by supporting numerous charity and social institutions. It, among others, supports the Association for the Fight against Cancer in Alahsa, and an association supporting people with Down Syndrome and Parkinson's disease. It also sponsors an early breast cancer detection program. The ANB supports a program developing technology for obtaining drinking water from sea water. It also fosters the continuous development of its employees, because, as it emphasizes, a strong team constitutes the basis of their strategic plan. The ANB also makes sure that the number of women working in 
the Bank at various positions increases and, through automation, it strives to improve the HR department, because, as the Management emphasizes, compliance with all the regulations related to employment is very important for the Bank.

Out of the banks in Kuwait, the Boubyan Bank and the Kuwait Finance House were selected for the study.

The Boubyan Bank was founded in 2004 in Kuwait. It operates in accordance with Sharia law and is part of the National Bank of Kuwait (NBK). In its financial statements, it emphasizes its compliance of the Zakat calculation with Sharia law, which is supervised by the Shariah Supervisory Board. To maintain the ethical and moral standards that are specific to Islam, the Bank has given up interest-based products. The Boubyan Bank participates in many charity campaigns and sponsors many institutions whose statutory goal is to help other people. It organizes the "Check Your Sweetness" program, which involves sugar-level testing for people of all ages. On the occasion of the Obesity Day, it also provided blood tests, including cholesterol tests, to thousands of people. It co-organized a campaign to save the eyesight of Ugandans, simultaneously giving out baskets with food, for which the Bank received a prestigious award: the Best Social Humanitarian Initiative of Private Sector Institutions. The Boubyan Bank's remuneration policy is in line with the Bank's strategic objectives. It primarily aims to attract, retain and motivate qualified employees, thus ensuring the proper functioning of the Bank. It also provides medical care, flight tickets and training. The entity consciously cares about the environment. As part of the National Bank of Kuwait and under its supervision, it implements numerous energy saving methods, uses the smallest amount of fresh water possible, reusing it wherever possible.

Another bank, the Kuwait Finance House (KFH), was founded in 1977 as the first Islamic bank in Kuwait. It is one of the main Sharia-law-based financial institutions in the world. In its annual reports, it underlines the fact that calculation of Zakat is always carried out in accordance with Sharia law, under the strict control of the body supervising the Bank's compliance with this law - the Fatwa and Shariah Supervisory Board. The Bank emphasizes that compliance with Sharia law is naturally linked to ethics and sustainable development. In its operation, the Bank avoids speculation and interest-based activity. It also cares for its employees by guaranteeing access to training and ensuring continuous professional development, offers health insurance and, if necessary, compensation. It emphasizes that human capital and its development are an integral part of the Bank's strategy. It also pays great attention to aid addressed to society. In response to the Rohingya refugee crisis in Bangladesh, the KFH donated $\$ 540000$ to support 3794 families. The bank also supports many organizations and charity campaigns, including the Kuwaiti Red Cross and the Association for the Care of Children in Hospitals. The KFH participates in many campaigns to raise awareness about cancer and diabetes as well as sponsors numerous forums and conferences raising public awareness of certain diseases. For this activity, it gained recognition of many leading national institutions, including the Kuwait Ministry 
of Health. According to the KFH, every company should care about its impact on the environment. The Bank undertakes a number of environmental-protection initiatives. For years, it has been participating in environmental-awareness projects and initiatives. The bank monitors the consumption of water, energy and paper, so as to reduce it, and participated in many environmental activities and events, such as the cleaning of beaches and planting of greenery. The Bank also places emphasis on the development of solar energy technology which could successfully replace the consumption of fossil fuel energy in Kuwait.

Out of the banks operating in Great Britain, the Al Rayan Bank as well as the Bank of London and the Middle East (BLME) were subject to analysis.

The Al Rayan Bank is the oldest Islamic retail bank in Great Britain. It was founded in 2004, with the headquarters in Birmingham. Its main goal is to conduct business in accordance with Sharia law, also in the field of Zakat calculation, which is supervised by the Shariah Supervisory Board established by the Bank. The Bank pays close attention to the appropriate work culture and environment. In 2018 it received the silver 'Investors in People' award, which reflects the Bank's contribution to employee development. What is more, it has been recognized as a 'Living Wage Employer' by the Living Wage Foundation, which means that the remuneration granted to employees is much higher than the national minimum wage. The Bank strongly emphasizes the implementation of Islamic moral and ethical norms, manifested in the fact that it does not invest in industries related to gambling, tobacco, alcohol, weapons and pornography, nor in other industries that are prohibited by Sharia law. It also avoids investment in derivatives and other instruments that are based on speculation, interest and high risk. Instead, it bases its activity on such assets as metals and real estate. This approach allowed the Al Rayan Bank to be recommended as an ethical alternative to conventional banks, awarded by the Move Your Money campaign, and to rank top of the Ethical Consumer Journal, among entities providing ethical bank accounts. The bank also supports many charities, including the Islamic Relief and National Zakat Foundation. It is also concerned with ecology, running programs educating people on how to care for and protect the environment. It puts great emphasis on the reduction of plastic and electricity consumption as well as eliminating food waste.

The second of the British banks examined is the Bank of London and the Middle East. It was founded in 2006 in London and became the largest Islamic bank in Europe. The company emphasizes the fact that its activity is entirely based on Sharia law. It particularly points to the fact of fair tax calculation in its Zakat report. It also underlines that all its activities are supervised by the Shariah Supervisory Board. Just like the Al Rayan Bank, it does not invest in the tobacco and alcohol industries, nor in gambling. It does not charge interest, which is illegal in Islamic accounting. This entity also invests its funds, contributing to the improvement of employees' health and well-being. It provides safe and healthy working conditions and numerous benefits, such as private medical care and gym membership. The BLME also underlines its 
efforts to reduce the negative impact on the environment. In its offices, it favourss recycling, while by promoting cycling, it encourages employees to eliminate cars when commuting to work.

Table 1. CSR in selected Islamic banks - summary

\begin{tabular}{|c|c|c|c|c|c|c|}
\hline $\begin{array}{l}\text { CSR tools } \\
\text { in Islamic } \\
\text { banks }\end{array}$ & Riyad Bank & ANB & $\begin{array}{l}\text { Boubyan } \\
\text { Bank }\end{array}$ & $\begin{array}{l}\text { Kuwait } \\
\text { Finance } \\
\text { House }\end{array}$ & $\begin{array}{l}\text { Al Rayan } \\
\text { Bank }\end{array}$ & BLME \\
\hline $\begin{array}{l}\text { Fairly calculate } \\
\text { Zakat }\end{array}$ & \multicolumn{6}{|c|}{ Confirmed by the independent Shariah Supervisory Board } \\
\hline $\begin{array}{l}\text { Pro-ecological } \\
\text { activities }\end{array}$ & \multicolumn{2}{|c|}{$\begin{array}{l}\text { Develops initiatives } \\
\text { dedicated to nature } \\
\text { protection }\end{array}$} & $\begin{array}{l}\text { Implements } \\
\text { energy } \\
\text { saving } \\
\text { methods }\end{array}$ & $\begin{array}{l}\text { Reduces } \\
\text { water, energy } \\
\text { and paper use }\end{array}$ & $\begin{array}{l}\text { Reduces } \\
\text { plastic and } \\
\text { electricity } \\
\text { use }\end{array}$ & \begin{tabular}{|l} 
Enables \\
recycling \\
in its offices
\end{tabular} \\
\hline $\begin{array}{l}\text { Employee } \\
\text { programs }\end{array}$ & \multicolumn{2}{|c|}{$\begin{array}{l}\text { Puts emphasis on } \\
\text { employees' development }\end{array}$} & $\begin{array}{l}\text { Motivates } \\
\text { employees, } \\
\text { provides } \\
\text { medical care }\end{array}$ & $\begin{array}{l}\text { Offers health } \\
\text { insurance, } \\
\text { puts } \\
\text { emphasis on } \\
\text { development }\end{array}$ & $\begin{array}{l}\text { Pays close } \\
\text { attention } \\
\text { to work } \\
\text { culture }\end{array}$ & $\begin{array}{l}\text { Provides } \\
\text { safe working } \\
\text { conditions, } \\
\text { benefits }\end{array}$ \\
\hline $\begin{array}{l}\text { Moral and } \\
\text { Ethical norms }\end{array}$ & \multicolumn{3}{|c|}{ Offers interest-free products } & \begin{tabular}{|l} 
Avoids \\
speculation \\
and interest- \\
based activity
\end{tabular} & \multicolumn{2}{|c|}{$\begin{array}{l}\text { Avoids investing in the } \\
\text { tobacco and alcohol } \\
\text { industries, does not charge } \\
\text { interest }\end{array}$} \\
\hline Charity & \multicolumn{6}{|c|}{ Sponsors many charity campaigns } \\
\hline
\end{tabular}

Source: own work based on information provided by selected Islamic banks.

The study shows that the Islamic banks are characterized by respect for Sharia law, and thus by high corporate social responsibility (Table 1). The banks not only emphasize the fair calculation of Zakat, supervised by relevant authorities, but also care for environmental protection, the dignified treatment of employees, ethical behaviour and charitable activity.

\section{Conclusion}

Based on the literature, it should be stated that Sharia law, according to which Islamic institutions operate, significantly affects their way of working, and in particular the implementation of the concept of corporate social responsibility, which in Islamic accounting is considered to be imperative.

The idea of social justice as one of the pillars of economic entity's functioning, is fulfilled when calculating Zakat in a fair manner, treating employees with dignity, caring for the natural environment, engaging in charitable work, guided in their activity by the ethical norms characteristic of Islam. The question arises, however, 
whether the entities that declare compliance with Sharia law, and thus should be guided by the idea of social justice, actually do so in practice.

Based on the analyses of financial statements and the information disclosed to the public, it can be concluded that the banks surveyed operate in accordance with Sharia law. These banks implement the concept of corporate social responsibility. Zakat is calculated fairly, which is confirmed by independent supervising institutions. In addition, all of the entities surveyed engage in helping communities around the world, as sponsors and even precursors of many charity campaigns. They also care for their employees, underlying their huge role in the Banks' strategy, often receiving prestigious awards for it. Environmental protection is also important for these banks - they not only run programs that raise awareness of the need to take care of the natural environment, but also make their own efforts to minimize the negative impact on the environment. In addition, some of the banks emphasize the fact that they do not invest in industries that are considered unethical - for example, the tobacco industries, thus underlining their full compliance with Islamic norms.

Banks, as financial institutions, strive to maximize profit. It can be stated, however, that Islamic entities do so in a sustainable manner, respecting the natural environment, the ethical and moral standards expressed in the Quran, society, the employees and their needs, thus fulfilling the overarching concept of Islamic accounting, namely corporate social responsibility.

\section{References}

Adamek, J. (2012). Kulturowe uwarunkowania rachunkowości w świetle założeń i praktyki rachunkowości islamskiej i chińskiej. Warszawa: CeDeWu.

Buczkowski, B., Dorożyński, T., Kuna-Marszałek, A., Serwach, T., \& Wieloch, J. (2016). Społeczna odpowiedzialność biznesu, Studia przypadków firm międzynarodowych. Łódź: Uniwersytet Łódzki.

Cieślewicz, N. (2013). Społeczna odpowiedzialność instytucji finansowych w Europie oraz w świecie islamu. Retrieved from http:/geopolityka.org/analizy/natalia-cieslewicz-spoleczna-odpowiedzialnosc-instytucji-finansowych-w-europie-oraz-w-swiecie-islamu

Janus, A. (2012). Bankowość islamska - panaceum na kryzys czy moralna fatamorgana. Prawo europejskie w praktyce, (04).

Jaworska, E. (2011). Specyfika rachunkowości islamskiej. Wybrane zagadnienia, Zeszyty Naukowe Uniwersytetu Szczecińskiego, Finanse, rynki finansowe, ubezpieczenia, (32).

Jusoh, W., \& Ibrahim, U. (2016). Corporate Social Responsibility of Islamic bank's practices: Exploratory studies. International Journal of Islamic Business Ethics (IJIBE), 1(2).

Koneczna, R. (2014). CSR i jego narzędzia jako element strategii firm - praktyczny przewodnik. Kraków: Wydawnictwo IGSMiE PAN.

Korenik, D. (2011). Kontrowersje wokół społecznej odpowiedzialności banków komercyjnych. Prace Naukowe Uniwersytetu Ekonomicznego w Wrocławiu, (171).

Rojek-Nowosielska, M. (2017). Definicja CSR według normy ISO 26000 a praktyka gospodarcza. Ruch Prawniczy, Ekonomiczny i Socjologiczny, (3).

Rybak, M. (2001). Etyka menadżera - społeczna odpowiedzialność biznesu - idea i rzeczywistość. Gospodarka Narodowa, (3). 
Waliszewski, K. (Ed.). (2018). Społeczna odpowiedzialność instytucji finansowych - od teorii do praktyki. Warszawa: CeDeWu.

Wielka Encyklopedia PWN. (2005). Warszawa: Wydawnictwo Naukowe PWN.

Zaman, A. (2005). Islamic economics: A survey of the literature, International Institute of Islamic Economics. Birmingham: University of Birmingham.

\section{SPOLECZNA ODPOWIEDZIALNOŚĆ BIZNESU W BANKACH ISLAMSKICH}

Streszczenie: Celem głównym autora artykułu było zbadanie, na ile banki działające zgodnie z prawem szariatu za nadrzędną uznają koncepcję społecznej odpowiedzialności biznesu. Postawiono tezę, iż religia islamu w znaczny sposób przyczynia się do stosowania tej koncepcji w islamskich instytucjach finansowych. W celu weryfikacji tej tezy wykorzystano metody studiów literatury przedmiotu oraz indukcji. Ponadto zbadano informacje podawane przez wybrane banki prowadzące działalność zgodnie z prawem szariatu z siedzibami w Wielkiej Brytanii, Arabii Saudyjskiej oraz Kuwejcie. Przeprowadzone badanie pozwala na wyciągnięcie wniosków, iż prawo szariatu w sposób istotny oddziałuje na koncepcję społecznej odpowiedzialności biznesu w islamskich instytucjach finansowych. Koncepcja ta uznawana jest przez islam za nadrzędną w funkcjonowaniu podmiotów. Jak wiadomo, każda instytucja działa po to, żeby przynosić zysk. W funkcjonowaniu islamskich podmiotów ważne jest jednak, żeby jednostka, osiągając zysk, nie zapomniała o charakterystycznych dla islamu normach moralno-etycznych oraz, co najważniejsze, o sprawiedliwej kalkulacji podatku.

Słowa kluczowe: społeczna odpowiedzialność biznesu, rachunkowość islamu. 